\title{
EIJEST STUDY OF FREE FLOW BELOW VERTICAL SLUICE GATE WITH POSITIVE STEP IN RADIAL STILLING BASIN*
}

\author{
Amany A. Habib** \\ Water \& Water Structures Eng. Dept., Zagazig Univ., Egypt
}

\begin{abstract}
Vertical sluice gates are widely used for flow control in irrigation and drainage channels. They may be used in prismatic or in non-prismatic channels. Steps may be constructed in stilling basins based on land topography and design requirements for the purpose of increasing the energy dissipation and reducing the length of hydraulic jump. The objective of the present study is to investigate the effect of a positive step located in radial stilling basin on the discharge of a free flow gate conditions. A diverging channel reach with fixed length and constant divergence angle is used. The effects of different relative height and relative positions of positive step on the coefficient of discharge below the gate are investigated experimentally. Also an experimental investigation was conducted to evaluate the effect of using sloping steps instead of the vertical steps on the discharge coefficient of the gate. The dimensional analysis was used to correlate the discharge coefficient to the other relevant flow and step parameters. It is found that the presence of positive step down stream the gate in a radial stilling basin increases the discharge coefficient and the percentage of increase increases with the sloping step. It is found also that the percentage of increase in the discharge coefficient reduces with the increase in step relative position. Dimensionless general equations in terms of the flow and step parameters for computing the coefficient of discharge of the sluice gate is developed using the multiple regression analysis.
\end{abstract}

KEY WORDS: Sluice Gate, Radial Stilling Basin, Positive Step, Discharge Coefficient, Sloping Step

\section{ÉTUDE DE LIBRE CIRCULATION EN DESSOUS VANNE VERTICAL AVEC STEP POSITVE EN RADIAL BASSIN D'AMORTISSEMENT}

\section{RÉSUMÉ}

Vannes verticales sont largement utilisés pour le contrôle de flux dans les canaux d'irrigation et de drainage. Ils peuvent être utilisés dans prismatiques ou dans des canaux non prismatiques. Des mesures peuvent être construits dans des bassins de tranquillisation basée sur la topographie des terres et des exigences de conception dans le but d'augmenter la dissipation de l'énergie et de réduire la longueur du saut hydraulique. L'objectif de la présente étude est d'étudier l'effet d'une étape positive dans le bassin de dissipation situé radiale sur la décharge d'une porte de conditions libres de flux. Une portée canal divergent avec une longueur fixe et l'angle de divergence constante est utilisée. Les effets de la hauteur relative différents et les positions relatives de l'étape positive sur le coefficient de débit en dessous de la porte sont étudiés expérimentalement. Aussi une étude expérimentale a été menée pour évaluer l'effet de l'utilisation des mesures pente au lieu des étapes verticales sur le coefficient de décharge de la porte. L'analyse dimensionnelle a été utilisée pour corréler le coefficient de décharge à la circulation d'autres paramètres pertinents et étape. Il est constaté que la présence d'étape positive vers l'aval de la porte dans un bassin de tranquillisation radiale augmente le coefficient de décharge et le pourcentage d'augmentation augmenté avec l'étape en pente. Il est également constaté que le pourcentage d'augmentation du coefficient de décharge diminue avec l'augmentation de la position étape relative. Adimensionnels équations générales en termes de débit et les paramètres étape pour calculer le coefficient de décharge de la vanne est développé en utilisant l'analyse de régression multiple.

MOTS-CLES: Porte d'écluse, Radial bassin d'amortissement, étape positive, coefficient de débit, l'étape en pente

\footnotetext{
* Received: 20 / 11/2011, Accepted: 25/ 12/2012 (Original Paper)

** Contact author ( amanyhabib89@yahoo.com, +2 0100165 8377)
} 


\section{INTRODUCTION:}

Because gates are extensively used to control and regulate the discharge of flow in irrigation canals, an understanding of their hydraulic characteristics is essential. The flow from these gates may be free or submerged depending on the tail water depth. The flow characteristics beneath the gates have been studied extensively theoretically and experimentally by many researchers, e.g., Henery (1950), Henderson (1966), Rajratnam and Subramanya (1967), Rajratnam and Humphries (1982), Swamee (1992), Ohatsu and Yasuda 1994), Rajratnam (1997). Many others investigated the effect of constructing sills under sluice gates. Some of these studies dealt with the free flow, Ranja Raju and Visavadia (1979), Ranga Raju (1981), Abdelaal (1990), Negm et al. (1993, 1995). While other dealt with the submerged flow, El-Saiad et al. (1990, 1991), Negm and El-Saiad (1993) and Negm (1994). Other studies dealt with the effect of gate or sill configuration on the flow below the gate, (1995). Characteristics of flow below gates without sill in non-prismatic channels were studies by Negm et al. (2000 a, b) for free flow and by
Ibrahim (2000) for submerged flow. On the other hand, the hydraulic jump characteristics in nonprismatic channels were investigated by many investigators, Arbhabhirama and Abella (1972), Khalifa and Mcorquodale (1979), France (1981), and Abdel-Aal $(1999,2000)$. It was found that the radial basin was more effective in dissipating the energy than the rectangular one. Therefore, it is preferred to use the radial basins to ensure more safety of the hydraulic structures against failure and to be more economic. The present study investigates the discharge characteristics of gates upstream of diverging stilling basin with the presence of a positive step for free flow conditions to provide information about the effect of the step parameters on flow below free sluice gate. The study investigates also the effect of using sloping step instead of the vertical one on the discharge coefficient. Using multiple regression analysis, dimensionless equations are developed for predicting the coefficient of discharge for free sluice gate.

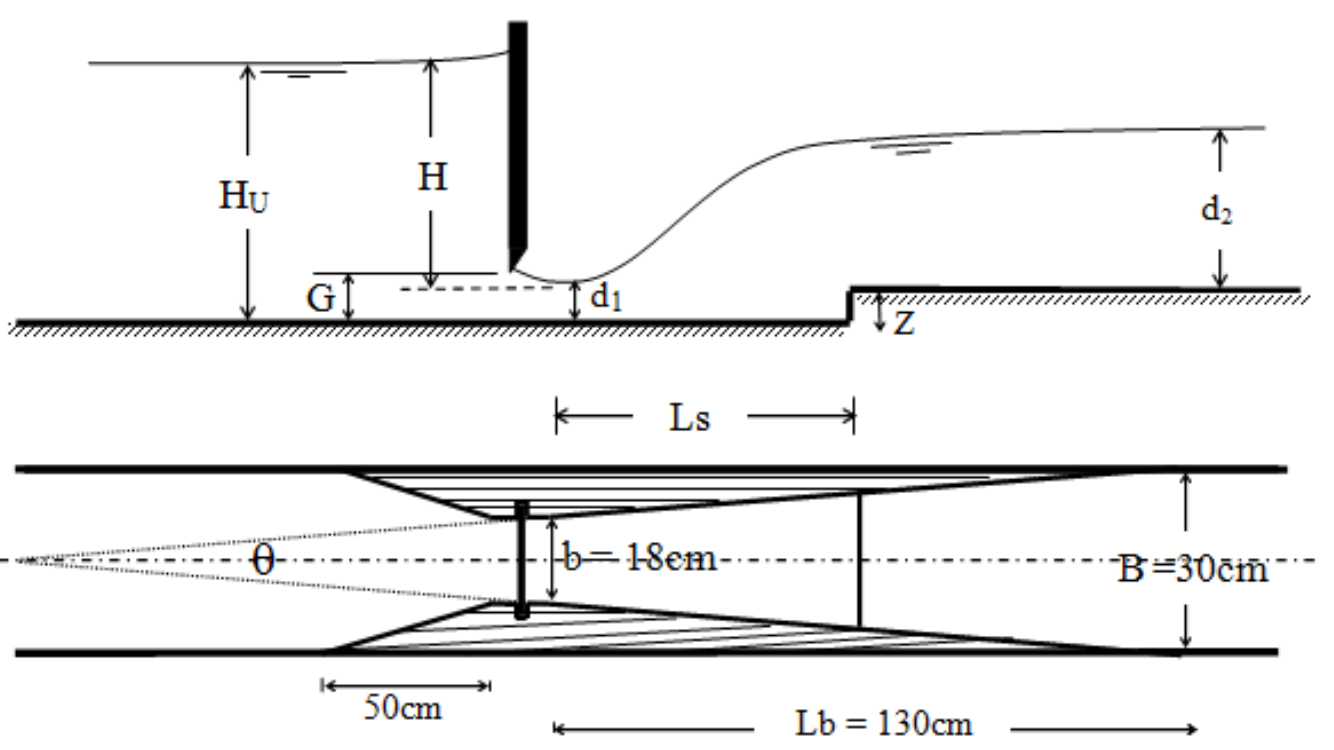

Fig. (1) Free flow below gate US horizontal radial stilling basin with positive step 


\section{THEORETICAL BACKGROUND}

Fig. (1) shows a typical definition sketch for free flow below sluice gate in radial stilling basin with positive step at different positions. Applying the principles of dimensional analysis, the following functional relationship for coefficient of discharge of the free sluice gate, $\mathrm{C}_{\mathrm{d}}$, can be proved as:

$\mathrm{C}_{\mathrm{d}}=f\left(\mathrm{Ls} / \mathrm{G}, \mathrm{Lb} / \mathrm{G}, \mathrm{Z} / \mathrm{G}, \mathrm{H}_{\mathrm{U}} / \mathrm{G}, \mathrm{F}_{\mathrm{G}}\right)$

OR $\quad \mathrm{C}_{\mathrm{d}}=f\left(\mathrm{Ls} / \mathrm{Lb}, \mathrm{Z} / \mathrm{G}, \mathrm{H}_{\mathrm{U}} / \mathrm{G}, \mathrm{F}_{\mathrm{G}}\right)$

discharge coefficient $\left(\mathrm{C}_{\mathrm{d}}\right)$ of sluice gate for free flow conditions shown in figure (1) is computed by using the following equation:

$$
\mathrm{C}_{\mathrm{d}}=\frac{\mathrm{Q}}{\mathrm{G} \times \mathrm{b} \times \sqrt{2 \times \mathrm{g} \times \mathrm{H}}}
$$

Where $\mathrm{G}$ is the gate opening height, $\mathrm{H}$ is the upstream water depth over vena-contracta, $b$ is the gate width, Q is the discharge passing through the flume, $g$ is the acceleration due to gravity, $\mathrm{Z} / \mathrm{G}$ relative height of positive step, $\mathrm{Ls} / \mathrm{Lb}$ is the relative position of step, and $\mathrm{F}_{\mathrm{G}}$ is the Froude number under the gate.

\section{EXPERIMENTAL SETUP}

The experimental work of this study was conducted using a re-circulating adjustable flume of $15.0 \mathrm{~m}$ long, $45 \mathrm{~cm}$ deep and $30 \mathrm{~cm}$ wide, Habib (2002). The discharges were measured using precalibrated orifice meter fixed in the feeding pipeline. The tailgate fixed at the end of the flume was used to control the tail-water-depth of flow. The radial basin was made from a clear prespex to enable visual inspection of the phenomenon being under investigation. The model length was kept constant at $130 \mathrm{~cm}$ and the angle of the divergence was kept constant to $5.28^{\circ}$ such that the expansion ratio is $1.67(\mathrm{~B} / \mathrm{b})$. The model was fixed in the middle third of the flume between its two side-walls as seen in Fig. (1). Different heights of the positive vertical step $(2.5,3.5,4.5$, and 5.5) are used at a different relative positions $(\mathrm{Ls} / \mathrm{Lb}=0.5,0.75$, and 1.0). The range of the experimental data were as follows: Froude numbers (2.3 - 6.7), $\mathrm{Z} / \mathrm{G}\left(0.45\right.$ - 2.7), and $\mathrm{H}_{\mathrm{U}} / \mathrm{G}(3.6-$ 23.5). The experimental investigation includes also three models of a sloping step of slopes (4:1, $8: 1$ and $12: 1)$ at $\mathrm{Ls} / \mathrm{Lb}=0.5$ and a height of $5.5 \mathrm{~cm}$ as shown in Fig. (2).

Each model was tested using five different gate openings and five discharges for each gate opening. A typical test procedure consisted of a gate opening was fixed and a selected discharge was
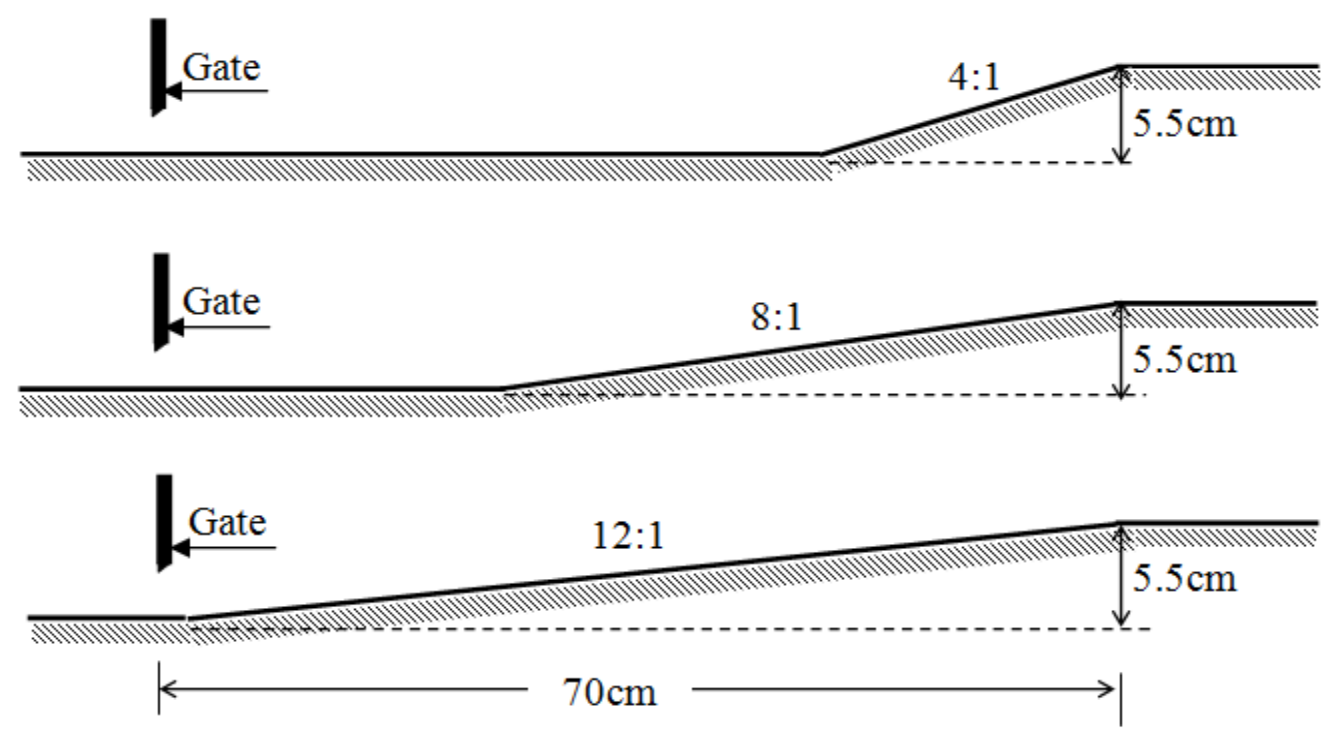

Fig. (2) Positive Sloping Step Models 


\section{Study of Free Flow Below Vertical Sluice Gate with Positive Step in Radial Stilling Basin}

Habib

allowed to pass then the tailgate was adjusted until a free perfect hydraulic jump is formed. Once the stability conditions were reached, the flow rate and water depths upstream and at the vena contracta downstream of the gate were recorded. These steps were repeated for different discharges and different gate openings and so on till the required ranges of the parameters being under investigation were covered.

\section{RESULTS AND DISCUSSIONS}

The discharge coefficient is taken as an indicator to study the effect of the different parameters of the positive step on the discharge and the case of flat bed (case of no step) is taken as a reference for the study to obtain the effect of the presence of rise (vertical or sloping positive step) on the discharge.

\subsection{Effect of Step Relative Height (Z/G)}

The variation of $C_{d}$ with $F_{G}$ and $H_{U} / G$ for different values of step relative height $(\mathrm{Z} / \mathrm{G})$ is shown in Figs. 3 and 4 at the three relative positions $(\mathrm{Ls} / \mathrm{Lb}=0.5,0.75$ and 1.0). It is observed that the values of $C_{d}$ increases with the increase in $\mathrm{Z} / \mathrm{G}$ for the tested ranges of $\mathrm{F}_{\mathrm{G}}$ and $\mathrm{H}_{\mathrm{U}} / \mathrm{G}$ for the different step relative positions comparing to the case without step $(\mathrm{Z} / \mathrm{G}=0.0)$. Table (1) shows the average percentages of increase of $C_{d}$ with positive step case compared with the case of flat bed.

\subsection{Effect of Step Relative Position (Ls/Lb)}

The variations of $\mathrm{C}_{\mathrm{d}}$ with $\mathrm{F}_{\mathrm{G}}$ and $\mathrm{H}_{\mathrm{U}} / \mathrm{G}$ for different values of step relative position are shown in Figs. 5 and 6 at different relative height of step $(\mathrm{Z} / \mathrm{G}=0.45$, $0.6,0.7, .85,1.2$ and 1.65$)$ respectively. It is observed that the values of $C_{d}$ increases with the presence of step compared with the case of flat bed. The percentage of increase decreases with the increase in $\mathrm{Ls} / \mathrm{Lb}$ for the tested ranges as shown in Table (1).

\subsection{Effect of Replacing Vertical Positive Step by Sloping Positive Step}

The variation of $\mathrm{C}_{\mathrm{d}}$ with $\mathrm{F}_{\mathrm{G}}$ for different step models (vertical, slope 4:1, slope $8: 1$, slope $12: 1$ and flat bed) at different relative height of step $(\mathrm{Z} / \mathrm{G}=0.9,1.1,1.4$, 1.6 and 2.7$)$ is shown in fig $(7 a, b, c, d, e)$ respectively. It is observed from the obtained results that the values of $\mathrm{C}_{\mathrm{d}}$ increases with the presence of the step compared the flat bed (without step) as previously mentioned. Also its observed that the using of sloping step instead of vertical one increases the discharge coefficient. The percentage of increase in $\mathrm{C}_{\mathrm{d}}$ with sloping step compared with the vertical step case increases with the increase in the slope of the step for the tested slopes. I.e. the maximum values of $\mathrm{C}_{\mathrm{d}}$ are attained at slope 12:1. Table (2) shows the average percentages of increase of $\mathrm{C}_{\mathrm{d}}$ with sloping step case compared with the case of vertical step for the three tested slopes.

\section{PREDICTION OF $\mathrm{C}_{\mathrm{d}}$}

Nonlinear and linear multiple regression analysis were used to analyze the experimental data. Many trials were made with different variables to obtain the best agreement between the experimental and the predicted values of $C_{d}$. The results of the best prediction trials are presented in Table (3). Also the predicted values are plotted against the experimental values and the residuals are plotted versus the predicted values as shown in Figs. 8 and 9. The results of the obtained models (linear and exponential) showed good agreement between the experimental and predicted values of $\mathrm{C}_{\mathrm{d}}\left(\mathrm{R}^{2}=0.93\right)$ and $\mathrm{R}^{2}$ between residuals and predicted values are $(2.5 \mathrm{E}-006$ and $1.45 \mathrm{E}-006)$ respectively.

Table (1) : Average percentages of increase of $C_{d}$ with +ve step compared with flat bed

\begin{tabular}{|c|c|c|c|}
\hline$Z / G$ & \multicolumn{3}{|c|}{$\%$ increase in discharge coefficient $\left(\mathbf{C}_{\mathbf{d}}\right)$} \\
\hline & $\mathbf{L s} / \mathbf{L b}=\mathbf{0 . 5}$ & $\mathbf{L s} / \mathbf{L b}=\mathbf{0 . 7 5}$ & $\mathbf{L s} / \mathbf{L b}=\mathbf{1 . 0}$ \\
\hline 0.45 & 1.062 & 0.885 & 0.731 \\
\hline 0.6 & 1.086 & 0.915 & 0.775 \\
\hline 0.7 & 1.164 & 1.007 & 0.838 \\
\hline 0.85 & 1.2 & 1.044 & 0.889 \\
\hline 1.2 & 1.362 & 1.224 & 1.078 \\
\hline 1.65 & 1.595 & 1.428 & 1.286 \\
\hline 2.3 & 2.1 & 2.00 & 1.992 \\
\hline
\end{tabular}



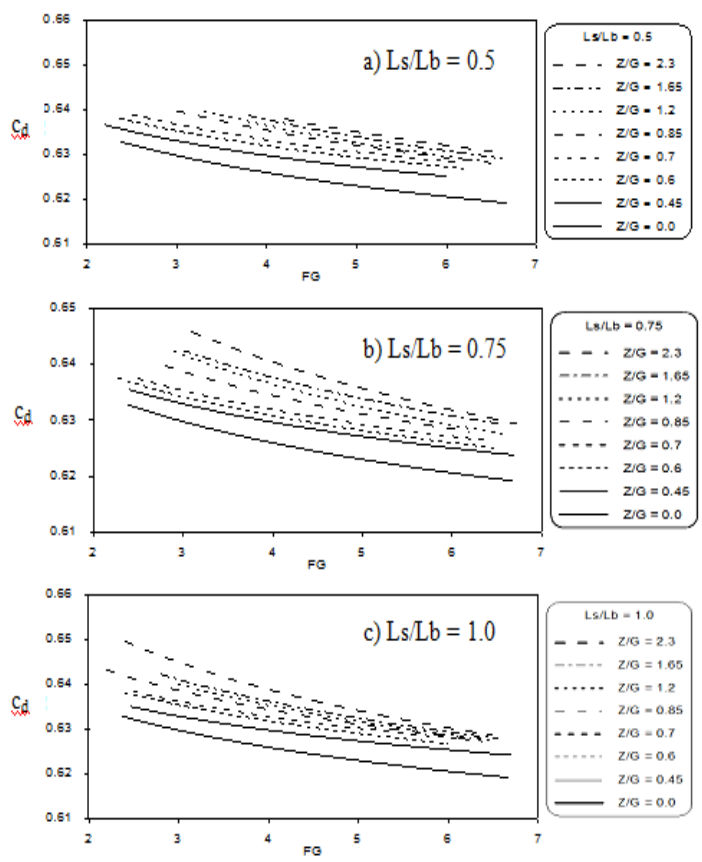

Fig. (3) Variation of $C_{d}$ with $F_{G}$ for different values of $\mathbf{Z} / \mathbf{G}$ at:

a) $\mathrm{Ls} / \mathrm{Lb}=0.5$, b) $\mathrm{Ls} / \mathrm{Lb}=0.75$ and $c) \mathrm{Ls} / \mathrm{Lb}=1.0$
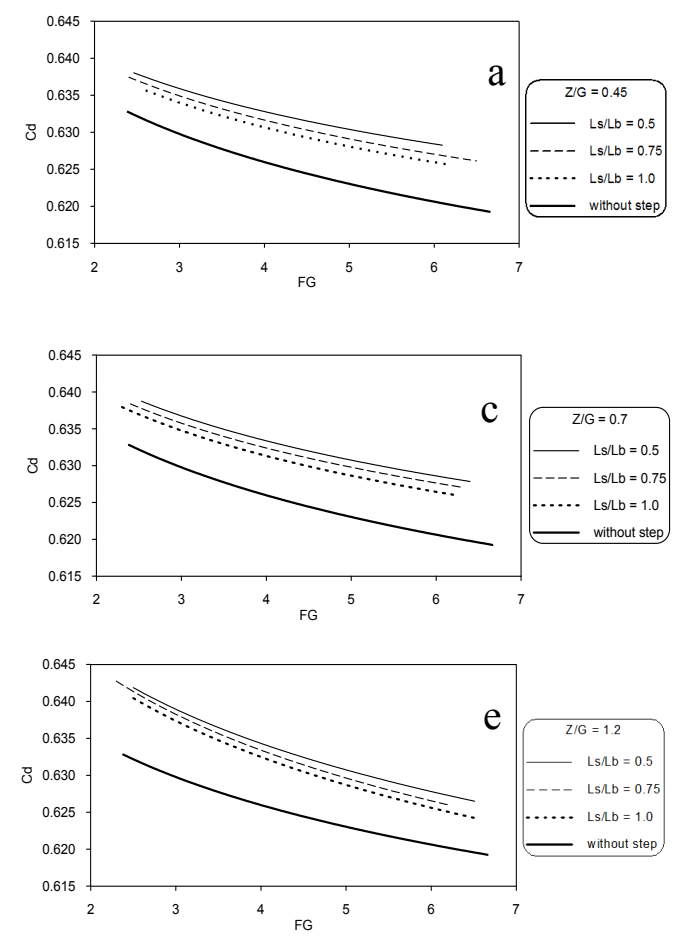
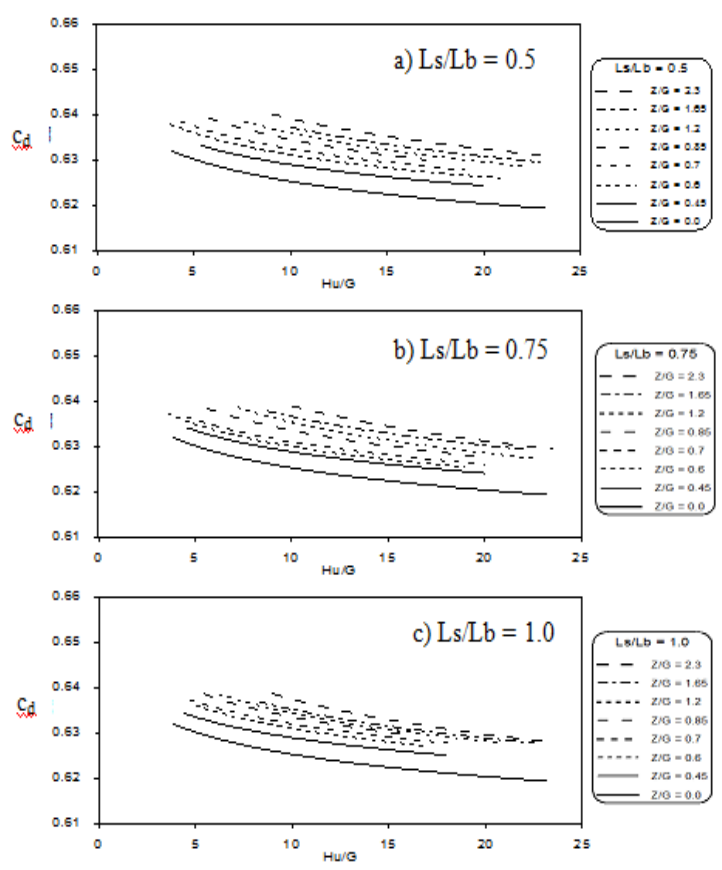

Fig. (4) Variation of $C_{d}$ with $H_{U} / G$ for different values of $\mathbf{Z} / \mathbf{G}$ at:

a) $L s / L b=0.5$, b) $L s / L b=0.75$ and c) $L s / L b=1.0$
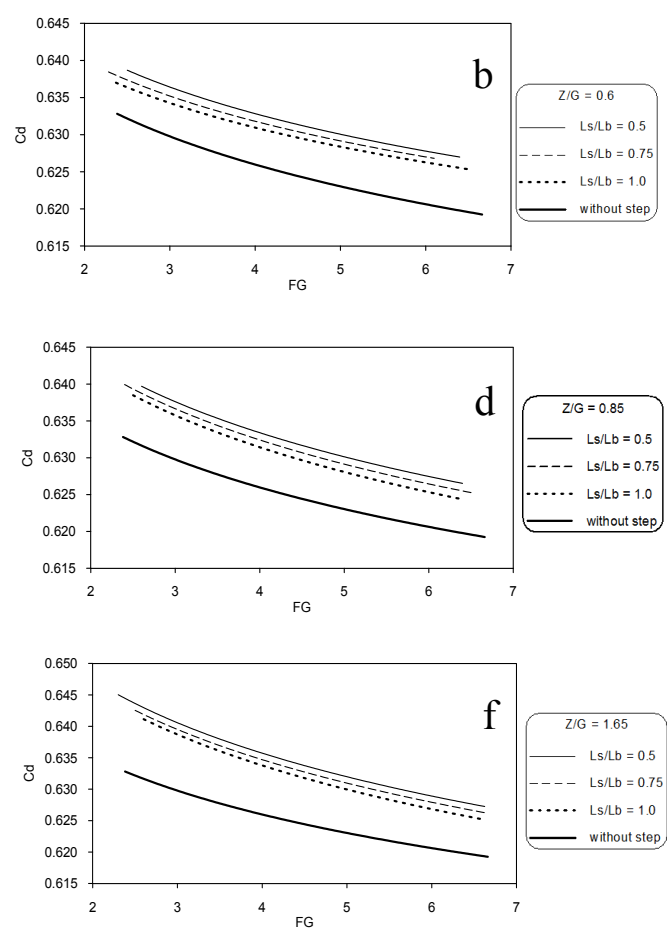

Fig. (5) Variation of $C_{d}$ with $F_{G}$ for different values of $L s / L b$ 
Study of Free Flow Below Vertical Sluice Gate with Positive Step in Radial Stilling Basin

Habib
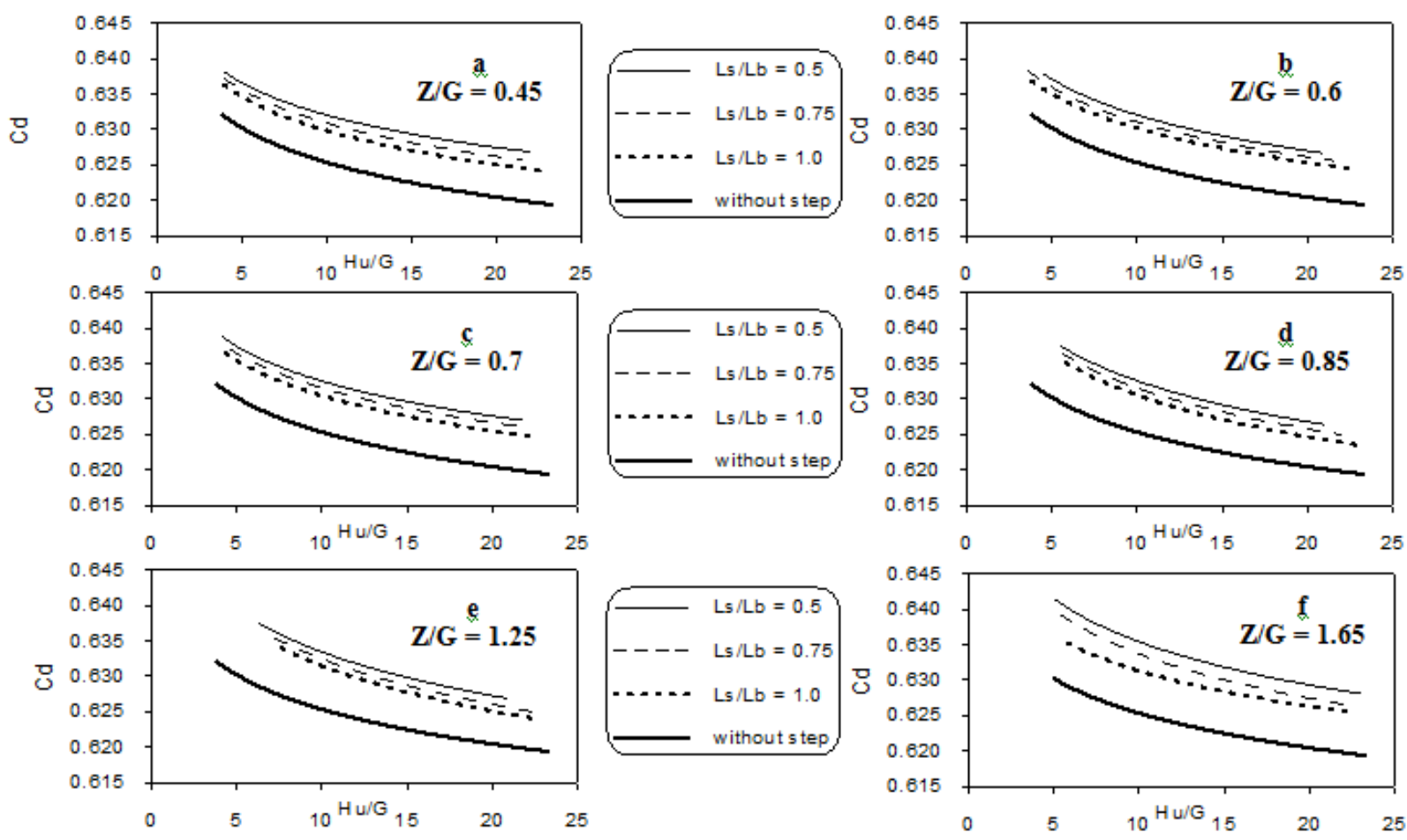

Fig. (6) Variation of $C_{d}$ with $H_{U} / G$ for different values of $L s / L b$ at various values of $Z / G$
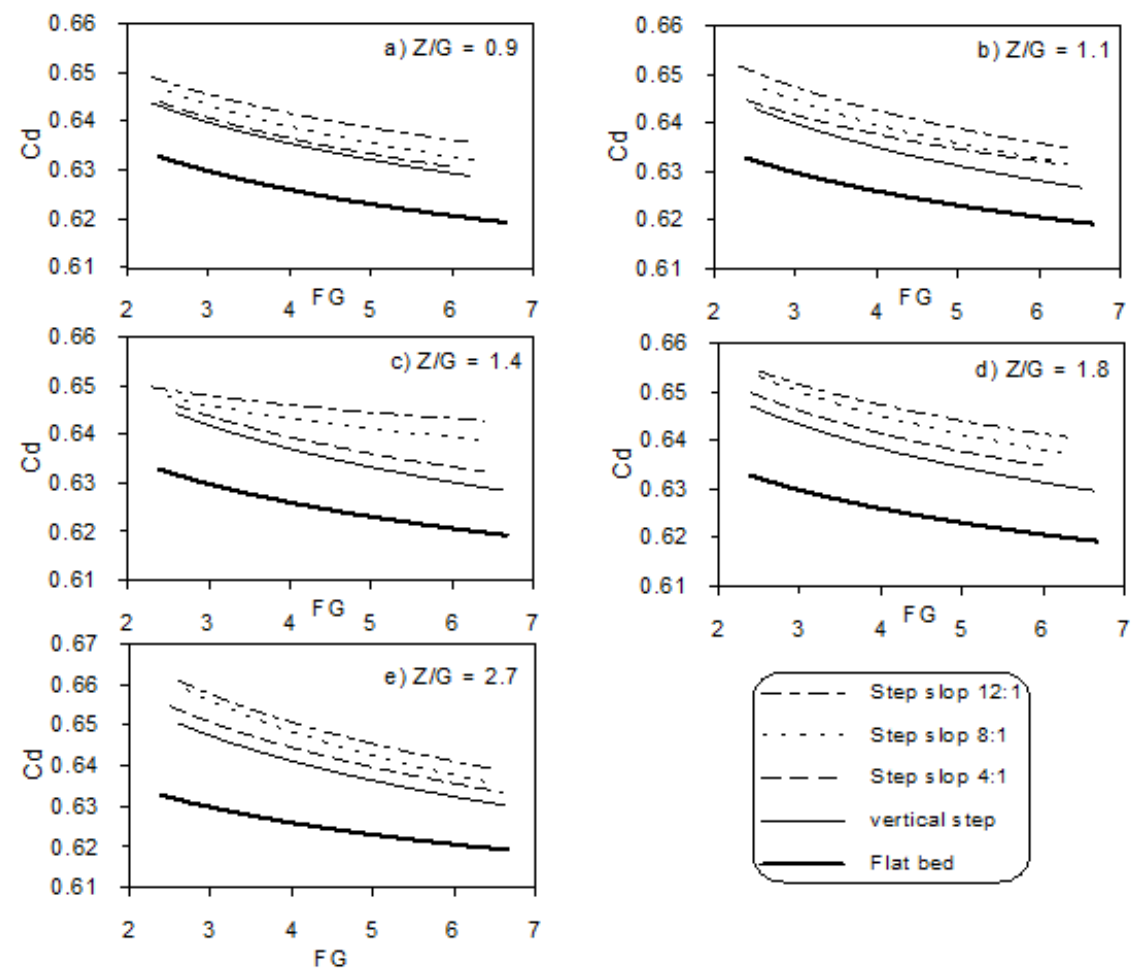

Fig. (7) Variation of $C_{d}$ with $F_{G}$ for different +ve step cases 
Table (2) : Average percentages of increase of $C_{d}$ with sloping step compared with the vertical step

\begin{tabular}{|c|c|c|c|}
\hline$Z / G$ & \multicolumn{3}{|c|}{$\%$ increase in discharge coefficient $\left(\mathbf{C}_{\mathbf{d}}\right)$} \\
\hline & Slope 4:1 & Slope 8:1 & Slope 12:1 \\
\hline 0.9 & 0.176 & 0.548 & 0.989 \\
\hline 1.1 & 0.389 & 0.734 & 1.195 \\
\hline 1.4 & 0.443 & 1.026 & 1.427 \\
\hline 1.6 & 0.494 & 1.057 & 1.475 \\
\hline 2.7 & 0.516 & 1.1 & 1.480 \\
\hline
\end{tabular}

Table (3) : Predicted Models of discharge coefficient

\begin{tabular}{|c|c|}
\hline Linear model & Exponential model \\
\hline $\begin{aligned} \mathrm{C}_{\mathrm{d}}= & -5.662 \mathrm{E}-03 \mathrm{Hu} / \mathrm{G}^{0.5} \\
& -4.944 \mathrm{E}-03 \mathrm{G} / \mathrm{Z} \\
& +4.892 \mathrm{E}-05 \mathrm{FG}{ }^{2} \\
& +1.049 \mathrm{E}-03 \mathrm{Lb} / \mathrm{Ls} \\
& +0.655\end{aligned}$ & $\begin{aligned} \mathrm{C}_{\mathrm{d}}=\exp & \left(-8.857 \mathrm{E}-03 \mathrm{Hu} / \mathrm{G}^{0.5}\right. \\
& -7.801 \mathrm{E}-03 \mathrm{G} / \mathrm{Z} \\
& +7.137 \mathrm{E}-05 \mathrm{FG}^{2} \\
& +1.654 \mathrm{E}-03 \mathrm{Lb} / \mathrm{Ls} \\
& -0.423)\end{aligned}$ \\
\hline
\end{tabular}

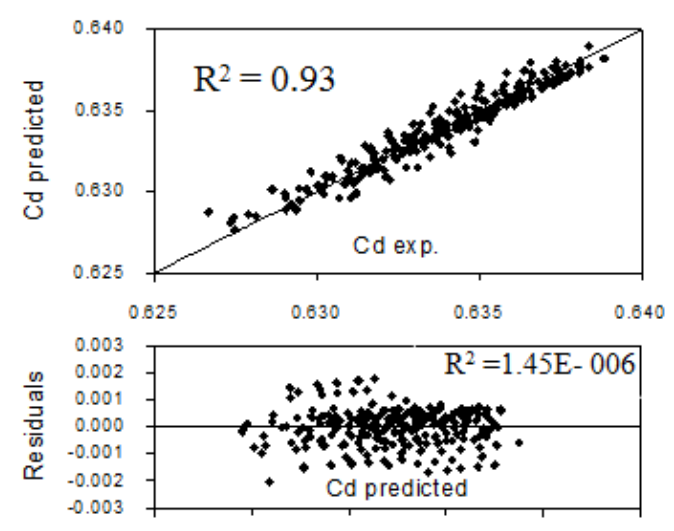

Fig. (8) Results of linear model

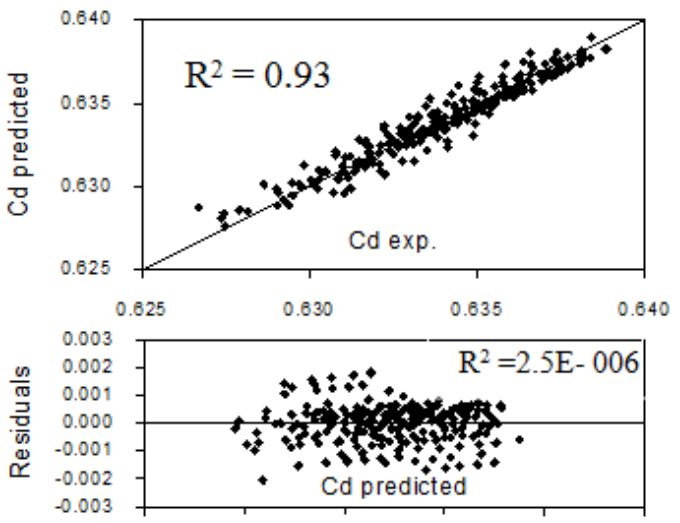

Fig. (9) Results of exponential model

\section{CONCLUSIONS}

An experimental investigation was conducted in a laboratory flume using vertical positive steps of different heights and at different positions in a radial stilling basin to investigate the effects of the step relative heights and relative positions on the discharge coefficient below free sluice gate upstream the basin. The experimental investigation includes also three models of sloping positive step at $\mathrm{Ls} / \mathrm{Lb}=0.5$ as an alternative to the vertical one. The experimental data were analyzed using the principles of dimensional analysis.

The results indicate that:

- The values of $C_{d}$ increases with the increase in $\mathrm{Z} / \mathrm{G}$ for the tested ranges of $\mathrm{F}_{\mathrm{G}}$ and $\mathrm{H}_{\mathrm{U}} / \mathrm{G}$ for the tested relative positions of the step comparing to the case without step $(\mathrm{Z} / \mathrm{G}=0.0)$.

- The percentage of increase in $C_{d}$ values with the presence of positive step decreases with the increase in $\mathrm{Ls} / \mathrm{Lb}$ for the tested ranges $\left[\max \mathrm{C}_{\mathrm{d}}\right.$ is attained at $\mathrm{Ls} / \mathrm{Lb}=0.5]$.

- Replacing a vertical positive step by a sloping one increases the discharge coefficient.

- The percentage of increase in $\mathrm{C}_{\mathrm{d}}$ with sloping step compared with the vertical step case increases with the increase in the slope of the step for the tested slopes [max $C_{d}$ is attained at slope 12:1]. 
Nonlinear and linear multiple regression analyses were used to analyze the experimental data. Two models are obtained in linear and exponential forms. The results of the obtained models (linear and exponential) showed good agreement between the experimental and predicted values of $\mathrm{C}_{\mathrm{d}}\left(\mathrm{R}^{2}=0.93\right)$ and $\mathrm{R}^{2}$ between residuals and predicted values are (2.5E-006 and 1.45E-006) respectively.

\section{REFERENCES}

1. Abdelaal, G.M.M., (1990), "Study of the Free Flow Conditions for Silled Gates", Unpublished M.Sc. Thesis, Faculty of Engineering, Ain Shams University, Cairo, Egypt.

2. Abdel-Aal, G.M., (1999),"Study of Hydraulic Jump in Gradually Expanding Rectangular Channels", Scientific Bulletin, Faculty of Engineering, Ain Shams University, Vol. 34, No. 4, pp. 339-351.

3. Abdel-Aal, G.M., (2000),"A Study of Stilling Basins in Non-Prismatic Channels", Scientific Bulletin, Faculty of Engineering, Ain Shams University, Vol. 35, No. 1, pp. 207222.

4. Arbhabhirama, A. and Abella, A.U., (1972), "Hydraulic Jump within Gradually Expanding Channel", Journal of the Hydraulic Division, Vol. 97, No. HY1, Jan., pp. 31-41.

5. El-Saiad, A., (1990), "Study of Submerged Flow Characteristics Under Silled Sluice Gates", Unpublished M.Sc. Thesis Ain Shams University, Cairo, Egypt.

6. El-Saiad, Atef A., Abdel Hafiz, Essam and Hammad, M. N., (1991), "Effect of Sill under gate on the discharge Coefficient"J. The Egyptian Society of Engineers, Vol.30, No.2, pp. 13-16.

7. France, P.W., (1981), "Analysis of the Hydraulic Jump within a Diverging Rectangular Channel", Proc. Instn., Civil Engineering, Part 2, June, 71, pp. 369-378.

8. Habib, A.A., (2002), "Characteristics of Flow in Diverging Stilling Basins", Unpublised
PH. D., Faculty of Engineering, Zagazig University.

9. Henderson, F.M., (1966), "Open Channel Flow", New York, Maemllan Publishing Co. Inc..

10. Henery, H., (1950), " Diffusion of Submerged Jets " Trans. Proc. ASCE, 115, pp. 687-697.

11. Ibrahim, A.A., (2000), "Analysis and Formulation of Supercritical Submerged Flow Below Gate in Radial Basin With Lateral Sill", Engineering Research Journal, Al-Mataria Faculty of Eng., HelwanUniversity, Vol. 68, April, pp. 117-130.

12. Khalifa, Abdelkawi M.,and Mcorquodale J.A., (1979), "Radial Hydraulic Jump", Journal of the Hydraulic Division, ASCE., Vol. 105, No. HY9, Proc. Paper 14825, September, pp. 1065-1078.

13. Negm, A.M., Abouelatta, N. and Abdellateef, M., (1993), "Supercritical Free Flow Characteristics under Silled Sluice Gate", Scientific Bulletin, Faculty of Engineering, Ain Shams University, Cairo, Egypt, pp.163-174.

14. Negm, A. M.; Abdellateef, M. and Owais, T. M., (1993) "Effect of Under-Ggate Sill Crest Shapes on the Flow Characteristics", Proc. of AEIC-93, 18-21 Dec., Faculty of Eng., AlAzhar University, Naser City, Cairo, Egypt, Vol.4, pp. 230-241.

15. Negm, A. M. and El-Saiad, A. A., (1993), "Subcritical Submerged Flow Characteristics Beneath Silled Sluice Gates" Proc. of AEIC93, December 18-21, Faculty of Engineering, Al-Azhar University, Naser City, Cairo, Egypt, vol.4, pp. 298-309.

16. Negm, A.M., (1994), "Optimum Relative Height of the Optimal Under-Gate Sill for Ssupercritical Submerged Flow Below Sluice Gates",19th Int. Conf. for Statistic, Computer Science, Scientific and Social Applications, 9 -14 April, Engineering Science, Cairo, Egypt, Vol.1, pp. 39-49.

17. Negm, A.M., Abdelaal, G. M., Owais, T. M., Abdellateef, M. and Hammad, M.N., (1995), "Characteristics of Free Hydraulic Jump Downstream Silled Sluice Gates",J. Water 
and Energy International, CBIP, India, pp.4551.

18. Negm, A.M., Abdel-Aal, G.M., El-Saiad, A.A. and Ibrahim, A.A., (2000a), "Characteristics Of Free Flow Below Gates In Sloping RadialStilling Basin", Proceeding of Al-Mansoura 3rd Int. Engineering Conference, April 11-13, Faculty of Engineering, El -MansouraUniversity, El-Mansoura, Egypt, Vol. 1, pp. 343-357.

19. Negm, A.M., Abdel-Aal, G.M., Ibrahim, A.A., and El-Saiad, A.A., (2000b), "Discharge Equation For Free Flow Below Gates Us Of Sloping Diverging Channel Reach", Egyptian Journal for Engineering Science and Technology (EJEST), Faculty of Engineering, Zagazig University, Zagazig, Egypt, Vol. 4, April, pp. 69-80.

20. Ohatsu, I. and Yasuda, Y., (1994) "Characteristics of Subcritical Flow Below Sluice Gate" Journal of Hydraulic Engineering, ASCE, 120, No. 3, pp. 332-346.

21. Rajratnam, N. and Subramanya. K., (1967), "Flow Equation for Sluice Gate" Journal of Irrigation and Drainage Division, ASCE, 93, No.4, pp. 167-186.

22. Rajratnam, N. and Humpries, J.A., (1982), "Free Flow Upstream of Vertical Sluice Gates ", Journal of Hydraulic Research, Vol. 20, No.5, pp. 427-437.

23. Rajratnam, N., (1997), "Free flow Immediately Below Sluice Gate." Journal of hydraulics division, ASCE, 102, No 4, pp. 345-351.

24. Ranja Raju, K.G. and Visavadia, D. S., (1979), "Discharge Characteristics of a Sluice Gate Located on a Raised Crest", Proc. IMEKO in Industry Tokyo, Japan, Nov., pp. 39-43.

25. Ranja Raju, K.G., (1981), "Flow through Open Channels", Tata McGraw Hill Publishing Company Limited, pp.246-247.

26. Swamee, P.K., (1992), "Sluice-Gate Discharge Equations" Journal of Irrigation and Drainage Engineering, Proc. ASCE, 118, No. 1, pp. 57-60. 